\title{
Is there an association of hematopoietic stem cell and endothelial progenitor cell markers with maturation in forearm arterial repair?
}

\author{
Hematopoetik kök hücre ve endotelyal progenitör hücre belirteçleri ile \\ önkolun arteriyel onarımındaki olgunlaşma arasında ilişki var mıdır?
}

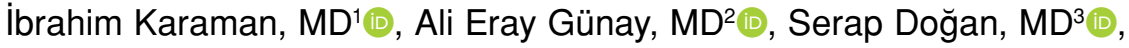

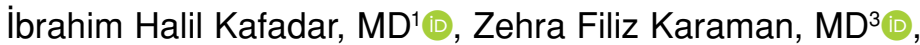 \\ 'Departments of Orthopaedics and Traumatology, Erciyes University Medical Faculty, Kayseri, Turkey \\ ${ }^{2}$ Department of Orthopaedics and Traumatology, Kayseri City Hospital, Kayseri, Turkey \\ ${ }^{3}$ Departments of Radiology, Erciyes University Medical Faculty, Kayseri, Turkey
}

\begin{abstract}
Objectives: This study aims to assess the effects of the hematopoietic stem cells and endothelial progenitor cells in peripheral blood and monocyte cluster of differentiation (CD) 34, CD133 and CD309 expression levels on maturation at the repair site in patients who underwent forearm arterial repair.

Patients and methods: This prospective study included 30 patients (23 males, 7 females; mean age $28.9 \pm 1.8$ years; range, 18 to 49 years) with a well-defined cut at the wrist due to a stabbing injury but no comorbid condition who presented to the emergency department of our hospital between November 2014 and November 2017. Vascular patency was assessed by Doppler sonography in patients who underwent forearm arterial repair via micro-vascular techniques. The relationships between patency and hematopoietic stem and endothelial progenitor cell markers such as CD34, CD133 and CD309 were assessed by flow cytometry.
\end{abstract}

Results: The patients were divided into two groups according to presence of sufficient flow in the arteries repaired. The mean CD34 expression level was $72.09 \pm 3.00$ in the group with maturation whereas it was $54.64 \pm 7.34$ in the group without maturation, indicating a statistically significant difference $(\mathrm{p}<0.05)$. In addition, the likelihood of sufficient flow was increased by 1.075 per one unit increase in CD34 level. Resistive index values were significantly lower in the group with maturation and CD34 level was predictive for maturation of arterial repair.

Conclusion: In the present study, the findings demonstrated that high CD34 expression level has favorable effects on maturation after arterial repair.

Keywords: Arterial recovery, cluster of differentiation 34, cluster of differentiation 133, cluster of differentiation 309 , endothelial progenitor cell.

\section{ÖZ}

Amaç: Buçalışmada, periferik kan ve monositlerdeki hematopoetik kök hücre ve endotelyal progenitör hücre farklılaşma yığılım molekülleri (CD) 34, CD133 ve CD309 ekspresyon düzeylerinin önkolun arteriyel onarımı yapılan hastalarda onarım sahasındaki olgunlaşma üzerindeki etkileri değerlendirildi.

Hastalar ve yöntemler: Bu prospektif çalışmaya elbileğinde saplanıcı bir yaralanmaya bağlı iyi tanımlanmış kesiği olup eşlik eden durumu olmayan, Kasım 2014 ve Kasım 2017 tarihleri arasında hastanemizin acil servisine başvuran 30 hasta (23 erkek, 7 kadın; ort. yaş $28.9 \pm 1.8$ yıl; dağılım, 18-49 yıl) dahil edildi. Önkolda mikrovasküler tekniklerle arteriyel onarım yapılan hastaların vasküler açıklığı Doppler sonografi ile değerlendirildi. Açıklık ve CD34, CD133 ve CD309 gibi hematopoetik kök ve endotelyal progenitör hücre belirteçleri arasındaki ilişkiler akış sitometrisi ile değerlendirildi.

Bulgular: Hastalar tamir edilen arterlerde yeterli akım olup olmamasına göre iki gruba ayrıldı. Ortalama CD34 ekspresyon düzeyi olgunlaşma olan grupta $72.09 \pm 3.00$ iken olgunlaşma olmayan grupta $54.64 \pm 7.34$ idi ve bu, istatistiksel olarak anlaml farklılığa işaret etti $(\mathrm{p}<0.05)$. Ek olarak, CD34 düzeyinde bir birim artış yeterli akış olasılığını 1.075 kat artırdı. Rezistif indeks değerleri olgunlaşma olan grupta anlamlı olarak daha düşük idi ve CD34 düzeyi arteriyel onarımın olgunlaşması için prediktif idi.

Sonuç: $\mathrm{Bu}$ çalışmada, bulgular yüksek CD34 ekspresyon düzeyinin arteriyel onarımdan sonra olgunlaşma üzerinde olumlu etkileri olduğunu gösterdi.

Anahtar sözcükler: Arteriyel iyileşme, farklılaşma yı̆̆ılım molekülleri 34, farklılaşma yığılım molekülleri 133, farklılaşma yığılım molekülleri 309, endotelyal progenitör hücre.

Received: February 25, 2019 Accepted: June 28, 2019 Published online: October 24, 2019

Correspondence: İbrahim Karaman, MD. Erciyes Üniversitesi Tıp Fakültesi Ortopedi ve Travmatoloji Anabilim Dalı, 38039 Melikgazi, Kayseri, Turkey. Tel: +90 352 - 4377163 e-mail: drikaraman@gmail.com 
Arterial injury is relatively uncommon among upper extremity injuries. However, it is often accompanied by tendon, muscle and bone injuries. The presence of two major arteries, namely the radial and ulnar arteries, and many perforating vessels prevents the development of ischemia. ${ }^{[1]}$ Although functional outcomes following injury depend on severity of injury, sufficient arterial flow is required for wound healing and better functional outcomes. ${ }^{[2]}$

With the advances seen in micro-vascular techniques, it has become more evident that outcomes in arterial repair are superior to those obtained by ligation in the absence of ischemia. ${ }^{[3]}$ Currently, Doppler sonography is the most commonly used technique in the assessment of arterial patency. ${ }^{[4]}$ Arterial stiffness and the resistive index (RI), which are known to be effective on long-term morbidity, can also be measured by Doppler sonography. ${ }^{[5,6]}$

Hematopoietic stem cells (HSCs) and endothelial progenitor cells (EPCs) reside in the bone marrow, they pass into the circulation and are involved in the healing process at the arterial repair site. It is thought that EPCs can be used as a marker for cardiovascular problems that may occur later in life and that lower levels are associated with higher risk. ${ }^{[7,8]}$ However, HSCs and EPCs and their effects on endothelialization are still controversial. ${ }^{[7]}$ Cluster of differentiation (CD) is a term used to classify cell surface markers. Currently, the combination of CD34, CD133 and CD309 (vascular endothelial growth factor-2 [VGEF-2], a specific endothelial cell marker) enables the identification of stem cells and progenitor cells..$^{[9,10]}$ Hematopoietic stem cells and EPCs express both hematopoietic (CD34) and endothelial cell markers (CD133 and CD309). ${ }^{[1]}$

In this study, we aimed to assess the effects of the HSCs and EPCs in peripheral blood and monocyte CD34, CD133 and CD309 expression levels on maturation at the repair site in patients who underwent forearm arterial repair.

\section{PATIENTS AND METHODS}

The study included 30 patients $(23$ males, 7 females; mean age 28.9 \pm 1.8 years; range, 18-49 years) with a well-defined cut at the wrist due to a stabbing injury but no comorbid condition who presented to the emergency department of Erciyes University Medical Faculty Emergency Department between November 2014 and November 2017. Patients with additional organ injury, bone injury or multiple arterial injuries, those who presented more than six hours after injury, and those with uncontrolled bleeding at the emergency department were excluded to standardize the severity of trauma. Arterial dissection was confirmed by Doppler sonography. In patients with active bleeding, the bleeding was controlled by a compressive bandage using gauze. A blood sample $(2 \mathrm{~mL})$ was drawn into ethylenediamine tetraacetic acid (EDTA) tubes at the sixth hour after trauma. The study protocol was approved by the Erciyes University Clinical Research Ethics Committee (approval date: August 08, 2014; no. 2014/518). A written informed consent was obtained from each patient. The study was conducted in accordance with the principles of the Declaration of Helsinki.

All patients were operated on under general anesthesia at the sixth hour after trauma by the same surgical team. Following the application of a tourniquet, the cut was explored and dissected structures were recorded. The tendons were sutured by using a modified Kessler technique; next, vascular and neuronal repairs, if required, were performed under microscope via micro-surgery techniques by using 10/0 Polyamide (Ethicon; Ethilon ${ }^{\circledR}$, Minneapolis, MN, USA) sutures. After completion of the repair, the tourniquet was released and blood flow was observed in the artery repaired. The milking test was used to control blood flow. In all patients, a short-arm splint in the functional position was applied after surgery. The splint was removed at week three in patients without tendon dissection and at week six in those with comorbid tendon dissection. Active arm movements were allowed in those without tendon dissection while early passive movements were started on day three in those with tendon dissection. No anticoagulant agent was used following surgery. For prophylaxis, a single dose of ampicillin-sulbactam was given one hour before surgery.

Sonographic evaluations were performed in the supine position via a GE Logiq S7 Expert Doppler Ultrasound system (GE Healthcare ${ }^{\circledR}$ Seoul, Korea) by a single operator. All evaluations were performed by using a $9 \mathrm{MHz}$ multi-linear array probe.

At week six after surgery, peak systolic velocity (PSV), end-diastolic velocity (EDV) and blood flow rate $(\mathrm{mL} / \mathrm{minute})$ were measured at distal and proximal positions to the repair site in the radial and ulnar arteries in the involved extremity and at the same level as determined by measurement of the distance from the wrist line in the uninvolved extremity.

Flow ratio was obtained by dividing the blood flow rate at the distal position to the involved artery by the blood flow rate of the same artery at the uninvolved 
side. Patients with a flow ratio $<50 \%$ were defined as having an insufficient blood flow rate (group 1) while those with a flow ratio $>50 \%$ were defined as having a sufficient blood flow rate (group 2). ${ }^{[12]}$ The RI was calculated by using PSV and EDV $[\mathrm{RI}=(\mathrm{PSV}-\mathrm{EDV}) /$ PSV]. The RI $>0.7$ indicates strong resistance in the artery, namely insufficient maturation.

In our study, blood samples with EDTA as anticoagulant were used for flow cytometry. Two tubes including an isotype control panel and CD34CD133 panel were prepared for each sample obtained from patients and controls. Flow cytometry analyses were performed by using a Beckman Coulter Navios flow cytometer (Brea, CA, USA) and Kaluza software. The results were presented as number of leukocytes expressing CD34, CD133 and CD309.

\section{Statistical analysis}

Data were analyzed by using the IBM SPSS version 22.0 (IBM Corp., Armonk, NY, USA) and MedCalc 9.2.0.1 software (Medcalc Software, Ostend, Belgium). The chi-square test was used to compare categorical variables. TheShapiro-Wilk test was used to test normal distribution of quantitative data. The independent samples t-test was used to compare data with normal distribution while the Mann-Whitney U test was used to compare data with skewed distribution (CD133, CD309 and age). Quantitative data are presented as the arithmetic mean \pm standard error and median (min-max). The Spearman's correlation analysis was used to assess the relationship between quantitative data. To assess the likelihood of having sufficient blood flow, binary logistic regression analysis was performed with several independent variables. Since the odds ratio was found to be extremely high for RI levels, it was taken as RIx10. In addition, receiver operating characteristic (ROC) analysis was performed for CD34, CD133 and CD309. A $p$ value $<0.05$ was considered as statistically significant.

\section{RESULTS}

There was radial artery injury in 13 and ulnar artery injury in 17 patients. The injury involved the right wrist in $18(60 \%)$ and the left wrist in 12 patients $(40 \%)$. Of the patients, 29 were right-handed while only one patient was left-handed and had a left ulnar artery injury. The mean length of the cut was $4.86 \pm 047 \mathrm{~cm}$. Cuts from broken glass were the most common cause of injury (83.34\%). No significant difference was found in age, gender, site and injured artery between groups (Table I).

There was isolated artery injury in three patients while additional tendon and/or nerve injury was present in 27 patients $(90 \%)$. The mean number of tendon injuries was $4.1 \pm 0.58$ in these patients. Median nerve injury alone was present in two patients whereas superficial radial nerve injury alone was present in three patients; ulnar nerve injury alone occurred in

TABLE I

Distribution of age (mean \pm standard error), gender, involved side, injured arteries and nerves

\begin{tabular}{|c|c|c|c|c|c|c|c|c|c|c|}
\hline \multirow[t]{2}{*}{ Characteristics } & \multicolumn{3}{|c|}{ Group $1(n=8)$} & \multicolumn{3}{|c|}{ Group $2(\mathrm{n}=22)$} & \multicolumn{3}{|c|}{ Total } & \multirow[b]{2}{*}{$p$} \\
\hline & $\mathrm{n}$ & $\%$ & Mean $\pm S D$ & $\mathrm{n}$ & $\%$ & Mean $\pm S D$ & $\mathrm{n}$ & $\%$ & Mean $\pm S D$ & \\
\hline Age (year) & & & $25.1 \pm 2.1$ & & & $30.3 \pm 2.3$ & & & $28.9 \pm 1.8$ & 0.219 \\
\hline Gender & & & & & & & & & & 1.000 \\
\hline Female & 2 & 25.0 & & 5 & 22.7 & & 7 & 23.3 & & \\
\hline Male & 6 & 75.0 & & 17 & 77.3 & & 23 & 76.7 & & \\
\hline Involved side & & & & & & & & & & 0.678 \\
\hline Right & 4 & 50.0 & & 14 & 63.6 & & 18 & 60.0 & & \\
\hline Left & 4 & 50.0 & & 8 & 36.4 & & 12 & 40.0 & & \\
\hline Injured artery & & & & & & & & & & 1.000 \\
\hline Radial & 3 & 37.5 & & 10 & 45.5 & & 13 & 43.3 & & \\
\hline Ulnar & 5 & 62.5 & & 12 & 54.5 & & 17 & 56.7 & & \\
\hline Injured nerve & & & & & & & & & & 0.813 \\
\hline No injury & 2 & 25.0 & & 9 & 40.9 & & 11 & 36.7 & & \\
\hline Radial & 1 & 12.5 & & 2 & 9.1 & & 3 & 10.0 & & \\
\hline Median & 1 & 12.5 & & 1 & 4.5 & & 2 & 6.7 & & \\
\hline Ulnar & 2 & 25.0 & & 7 & 31.8 & & 9 & 30.0 & & \\
\hline Ulnar + median & 2 & 25.0 & & 3 & 13.6 & & 5 & 16.7 & & \\
\hline
\end{tabular}

SD: Standard deviation. 
TABLE II

Comparison of Doppler sonography results and cluster of differentiation levels between groups

\begin{tabular}{|c|c|c|c|c|c|c|c|}
\hline & \multicolumn{3}{|c|}{ Group $1(n=8)$} & \multicolumn{3}{|c|}{ Group 2 (n=22) } & \multirow[b]{2}{*}{$p$} \\
\hline & Mean $\pm S E$ & Median & Min-Max & Mean $\pm S E$ & Median & Min-Max & \\
\hline Resistive index & $0.8 \pm 0.0$ & 0.75 & $0.64-0.86$ & $0.7 \pm 0.0$ & 0.65 & $0.40-0.89$ & 0.031 \\
\hline CD34 & $54.6 \pm 7.3$ & 61.00 & $10.00-78.00$ & $72.1 \pm 3.0$ & 70.00 & $42.0-105.0$ & 0.013 \\
\hline CD133 & $34.4 \pm 4.4$ & 35.00 & $23.00-56.00$ & $43.9 \pm 5.0$ & 37.50 & $10.00-103.0$ & 0.284 \\
\hline CD309 & $6.6 \pm 0.7$ & 7.00 & $5.00-10.00$ & $8.9 \pm 1.0$ & 8.00 & $4.00-16.00$ & 0.068 \\
\hline
\end{tabular}

SE: Standard error; Min: Minimum; Max: Maximum; CD: Cluster of differentiation.
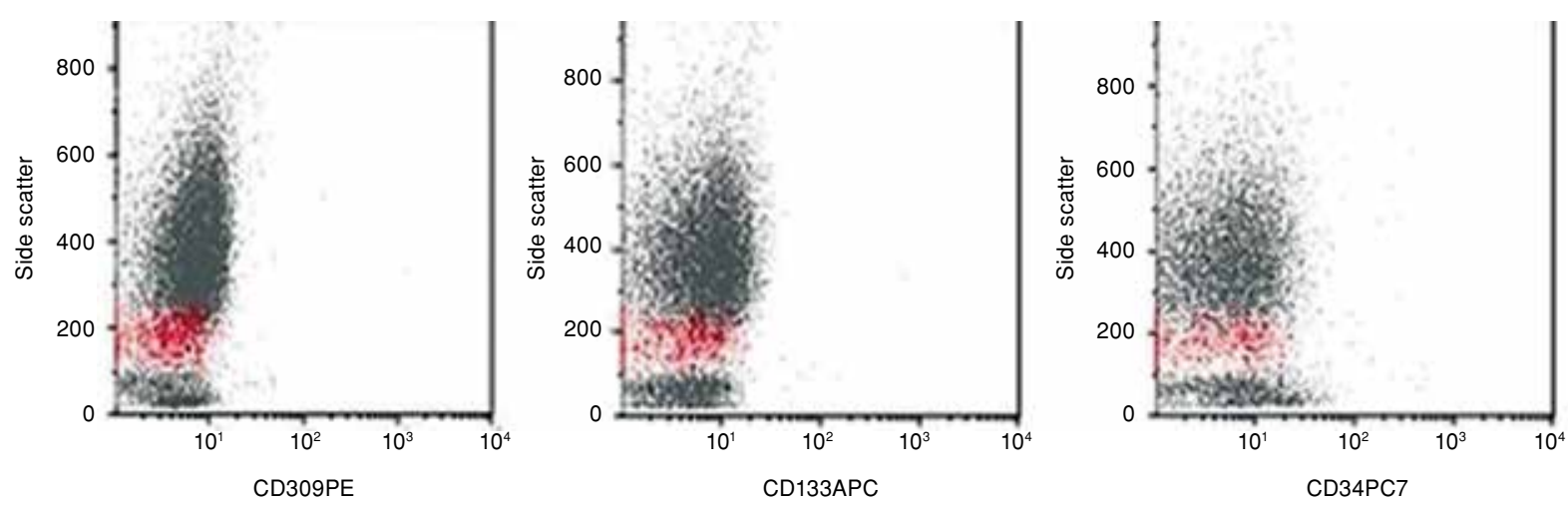

Figure 1. Cluster of differentiation 34, 133, 309 surface expression in patients.

CD: Cluster of differentiation; SS: Side scatter; PE: Phycoerythrin; APC: Allophycocyanin; PC7: Phycoerythrin-Cyanine 7.

nine patients and median plus ulnar nerve injury in five patients. There was a moderate, positive correlation between length of cut and number of tendon injuries ( $r=0.591 ; \mathrm{p}=0.001)$.

By using the data obtained from Doppler sonography, the flow ratio was obtained by dividing the blood flow rate at the distal position to the involved artery by the blood flow rate of the same artery at the uninvolved side. Based on flow ratio, the flow was estimated as insufficient in eight patients (group 1) while it was sufficient in 22 patients (group 2).
The RI was found to be significantly higher in group 1 than in group $2(\mathrm{p}<0.05)$. When the flow cytometry results were considered, it was found that CD34 cells were significantly higher in group 2 $(\mathrm{p}<0.05)$ while CD133 and CD309 cells were higher in group 2 but the difference did not reach statistical significance (Table II, Figure 1).

In logistic regression, it was found that the likelihood of sufficient flow was increased by 1.075 per one unit increase in CD34 level $(\mathrm{p}<0.05)$ (Table III).

In ROC analysis, the area under the curve was calculated as 0.724 for CD34 and 0.734 for RI. The cut-

\section{TABLE III}

Univariate binary logistic regression analysis for factors with potential to influence achievement of sufficient flow

\begin{tabular}{lccc}
\hline & $\mathrm{B}$ & $\mathrm{OR}(95 \% \mathrm{Cl})$ & $p$ \\
\hline CD34 & -0.074 & $0,93(0.86-1.00)$ & 0.037 \\
CD133 & -0.027 & $0.97(0.93-1.02)$ & 0.285 \\
CD309 & -0.165 & $0.85(0.66-1.10)$ & 0.193 \\
Resistive index $\times 10$ & -0.866 & $2.38(0.91-3.20)$ & 0.077 \\
\hline
\end{tabular}

OR: Odds ratio; $\mathrm{Cl}$ : Confidence interval; CD: Cluster of differentiation. 
TABLE IV

Sensitivity and specificity of cluster of differentiation 34, 133, 309 and resistive index levels for sufficient blood flow rate

\begin{tabular}{lcccccccc}
\hline & AUC & Cut-off & Sensitivity (\%) & Specificity (\%) & +LR & -LR & PP & NP \\
\hline CD34 & 0.724 & 63.5 & 77.3 & 75.0 & 3.30 & 0.32 & 54.5 & 89.5 \\
CD133 & 0.597 & 27.0 & 86.4 & 50.0 & 3.67 & 0.58 & 57.1 & 82.6 \\
CD309 & 0.571 & 10.0 & 36.4 & 100.0 & 1.57 & 0.00 & 1.60 & 100.0 \\
RI & 0.734 & 0.64 & 100.0 & 45.5 & 1.83 & 0.00 & 36.8 & 100.0 \\
\hline
\end{tabular}

AUC: Area under curve; CD: Cluster of differentiation; +LR: +Likelihood ratio; -LR: -Likelihood ratio; PP: Positive predictive value; NP: Negative predictive value; RI: Resistive index.

off value was determined as 63.5 for CD34 (sensitivity: 77.3\% and specificity: 75\%) and 0.64 for RI (sensitivity: 100\% and specificity: $45.4 \%$ ) (Table IV, Figure 2). The cases were stratified into two groups according to CD34 level: group A, patients with CD34 level $\geq 63.5$ and group $\mathrm{B}$, patients with CD34 level <63.5. The groups were compared regarding sufficient blood flow rate (flow ratio $>50 \%$ ) by using the chi-square test and it was found that the proportion of patients with sufficient blood flow rate was higher in group A. No significant difference was found between groups $(\mathrm{p}<0.05)$.

\section{DISCUSSION}

To the best of our knowledge, there is no study investigating HSC and EPC level in maturation of forearm arterial repair in the literature. ${ }^{[13]}$ Thus, we designed the present study to assess the effects of HSC and EPC levels on maturation after forearm arterial repair. Our results showed that CD34 expression level had favorable effects on maturation after arterial repair, that it significantly decreased RI values, and

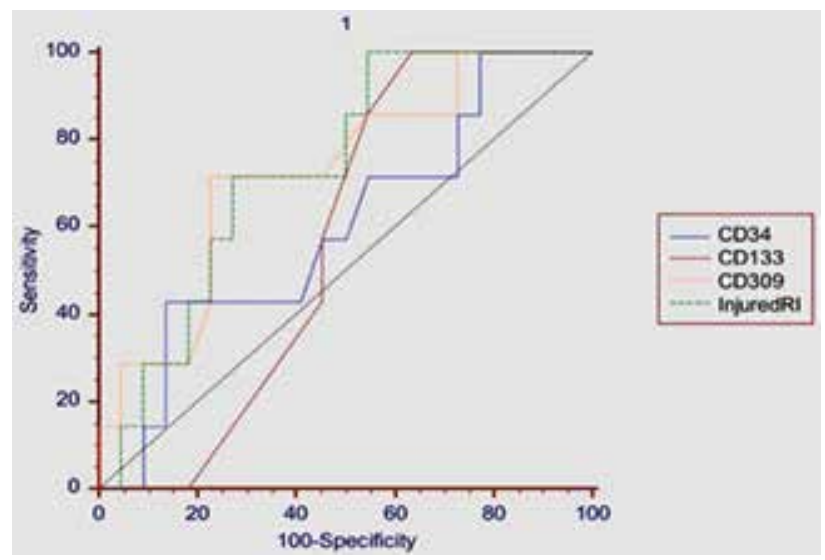

Figure 2. Sensitivity (100-specificity) of cluster of differentiation $34,133,309$ and resistive index levels for sufficient blood flow rate.

$\mathrm{CD}$ : Cluster of differentiation; RI: Resistive index. that it could be used as a predictor for maturation of arterial repair.

Surgeons experience a dilemma in deciding between repair and ligation when dealing with an arterial injury at forearm level since no hand ischemia is anticipated following single arterial injury due to abundant collateral network. These patients often have additional tendon, nerve and bone injuries. It was shown that outcomes regarding the functional recovery of additional injuries were better with lesser problems such as weakness or paresthesia and better nerve regeneration in patients who underwent arterial repair. ${ }^{[14]}$ In addition, it has been shown that there is lesser endothelial damage and better outcomes, after vessel repairs are achieved by using microsurgery techniques. ${ }^{[15,16]}$ Despite the lack of ischemic findings, we performed arterial repair via microsurgery techniques in our patients to achieve a better long-term outcome, which is in agreement with the literature.

Doppler sonography is a widely used technique in order to assess the repair site following arterial repair as it is a non-invasive and inexpensive modality. ${ }^{[17]}$ It allows the assessment of flow rate and characteristics as well measurement of arterial stiffness and RI values which are considered as risk factors for vascular diseases in the long-term. ${ }^{[4,18]} \mathrm{A}$ reduction is expected in flow rate in cases of occlusion or poor endothelialization, indicating incomplete maturation. ${ }^{[19]}$ Studies on the timing of Doppler sonography recommend that it should be performed at least three weeks after injury and that results should be interpreted by comparing them with the uninvolved side. ${ }^{[15]}$ In our study, we performed Doppler sonography at week six after surgery and compared arterial flow rates with the uninvolved side in the same patient. Blood flow was considered as occluded (insufficient maturation) if the blood flow rate was $<50 \%$ when compared to the uninvolved side while patent (sufficient maturation) if it was $>50 \%$. ${ }^{[12]}$ In our study, the blood flow rate was found to be 
$>50 \%$ in 22 of 30 patients. The CD34 level was found to be significantly higher in these patients with cut-off values of 63.5 and 0.64 for CD34 and RI, respectively. It was seen that arterial patency was maintained with better maturation and sufficient blood flow in patients with CD34 above the cut-off value. In addition, it was seen that RI values were significantly lower in these patients when compared to those with insufficient blood flow. In the literature, a RI value $>0.7$ was considered as a poor prognostic factor. ${ }^{[20]}$ In addition, it was shown that the likelihood of sufficient flow was increased by 1.075 per one unit increase in CD34 level, thus contributing to maturation.

Hematopoietic stem cells and EPCs express both hematopoietic (CD34) and endothelial cell markers (CD133, CD309-VGEFR-2). ${ }^{[9]}$ It has been observed that EPCs play a role in the endothelialization of the vascular injury site in addition to the promotion of angiogenesis. ${ }^{[21]}$ It was shown that EPCs reach their peak value 6-12 hours after trauma, returning to normal levels at $48-72$ hours. ${ }^{[2]}$ Thus, we assessed EPC and HSC levels in blood samples obtained at the sixth hour after trauma. Previous studies showed that HSC and EPC infusions after trauma improved endothelialization while decreasing neo-intimal hyperplasia. ${ }^{[23,24]}$ On the other hand, it is well-known that some agents (statins, erythropoietin, granulocytecolony stimulating factor [G-CSF]) enhance HSC and EPC release from bone marrow. ${ }^{[21]}$ Kong et al. ${ }^{[25]}$ observed an increase in endothelialization and a decrease in neo-intimal hyperplasia with G-CSF infusion in a rat model of angioplasty. In this study, we showed that maturation in the arterial repair site was better and that sufficient blood flow was achieved in patients with higher CD34 expression levels, which is present in hematopoietic precursor cells and capillary endothelial precursor cells and is used as a stem cell marker.

In the literature, many studies have shown the favorable effects of EPCs on the vascular healing process. In a study about the effects of EPCs on fistula maturation, Eroğlu et al. ${ }^{[26]}$ showed that high CD309 levels had a favorable effect. Moreover, in another study by Gill et al., ${ }^{[22]}$ it was suggested that CD309 and CD133 values were increased temporarily in the peripheral circulation at early phase in patients who underwent coronary artery bypass and in those with burn injury, thus improving revascularization in damaged tissues. In our study, CD309 and CD133 levels were found to be higher in patients with a sufficient blood flow rate although the difference did not reach statistical significance. We think that this increase in CD309 and CD133 levels is associated with better healing process, by providing sufficient blood flow rate.

This study has some limitations. First of all, the sample size was limited; thus, it is necessary to confirm these findings in a larger study population. In addition, the HSC and EPC values relied on a single measurement. Multiple measurements may provide more relevant results. Finally, long-term outcomes may provide more definitive information about the maintenance of maturation.

In conclusion, based on these results, there is a potential relationship between the CD34 level and maturation of arterial repair.

\section{Declaration of conflicting interests}

The authors declared no conflicts of interest with respect to the authorship and/or publication of this article.

\section{Funding}

This study was supported by the Erciyes University Medical Faculty Council of Scientific Investigations (Project Code TGS2014-5395).

\section{REFERENCES}

1. Haerle M, Tonagel F, Schaller HE. Collateral arterial pathways in the forearm. Surg Radiol Anat 2004;26:208-11.

2. Ballard JL, Bunt TJ, Malone JM. Management of small artery vascular trauma. Am J Surg 1992;164:316-9.

3. Bassetto F, Zucchetto M, Vindigni V, Scomparin MA, Corbetti F, Perissinotto E, et al. Traumatic musculoskeletal changes in forearm and hand after emergency vascular anastomosis or ligation. J Reconstr Microsurg 2010;26:441-7.

4. Rothkopf DM, Chu B, Gonzalez F, Borah G, Ashmead D 4th, Dunn R. Radial and ulnar artery repairs: assessing patency rates with color Doppler ultrasonographic imaging. J Hand Surg Am 1993;18:626-8.

5. Kuznetsova T, Cauwenberghs N, Knez J, Thijs L, Liu YP, Gu $\mathrm{YM}$, et al. Doppler indexes of left ventricular systolic and diastolic flow and central pulse pressure in relation to renal resistive index. Am J Hypertens 2015;28:535-45.

6. Pearce JD, Craven TE, Edwards MS, Corriere MA, Crutchley TA, Fleming $\mathrm{SH}$, et al. Associations between renal duplex parameters and adverse cardiovascular events in the elderly: a prospective cohort study. Am J Kidney Dis 2010;55:281-90.

7. Tilling L, Hunt J, Donald A, Clapp B, Chowienczyk P. Arterial injury and endothelial repair: rapid recovery of function after mechanical injury in healthy volunteers. Cardiol Res Pract 2014;2014:367537.

8. Schmidt-Lucke C, Rössig L, Fichtlscherer S, Vasa M, Britten M, Kämper U, et al. Reduced number of circulating endothelial progenitor cells predicts future cardiovascular events: proof of concept for the clinical importance of endogenous vascular repair. Circulation 2005;111:2981-7.

9. Lin Y, Weisdorf DJ, Solovey A, Hebbel RP. Origins of circulating endothelial cells and endothelial outgrowth from blood. J Clin Invest 2000;105:71-7. 
10. Peichev M, Naiyer AJ, Pereira D, Zhu Z, Lane WJ, Williams $\mathrm{M}$, et al. Expression of VEGFR-2 and AC133 by circulating human CD34(+) cells identifies a population of functional endothelial precursors. Blood 2000;95:952-8.

11. Asahara T, Murohara T, Sullivan A, Silver M, van der Zee R, $\mathrm{Li} \mathrm{T}$, et al. Isolation of putative progenitor endothelial cells for angiogenesis. Science 1997;275:964-7.

12. Lewis JE, Williams P, Davies JH. Non-invasive assessment of peripheral arterial disease: Automated ankle brachial index measurement and pulse volume analysis compared to duplex scan. SAGE Open Med 2016;4:2050312116659088.

13. Atik OŞ. Which articles do we prefer to publish? Eklem Hastalik Cerrahisi 2018;29:1.

14. Aftabuddin M, Islam N, Jafar MA, Haque E, Alimuzzaman M. Management of isolated radial or ulnar arteries at the forearm. J Trauma 1995;38:149-51.

15. Bacakoğlu A, Ozkan MH, Coşkunol E, Ozdemir O, Ekin A. Multifactorial effects on the patency rates of forearm arterial repairs. Microsurgery 2001;21:37-42.

16. Choi KL, Salman L, Krishnamurthy G, Mercado C, Merrill D, Thomas I, et al. Impact of surgeon selection on access placement and survival following preoperative mapping in the "Fistula First" era. Semin Dial 2008;21:341-5.

17. Keleş MK, Şimşek T, Polat V, Yosma E, Demir A. Evaluation of forearm arterial repairs: Functional outcomes related to arterial repair. Ulus Travma Acil Cerrahi Derg 2017;23:117-21.

18. Huang SS, Huang PH, Leu HB, Wu TC, Lin SJ, Chen JW. Association of central pulse pressure with contrast-induced nephropathy and clinical outcomes in patients undergoing coronary intervention. J Hypertens 2013;31:2187-94.
19. Boswick J. Injuries of the radial and ulnar arteries. In: Proceedings of the american society for surgery of the hand. J Bone Joint Surg 1967;49:582.

20. Viazzi F, Leoncini G, Derchi LE, Pontremoli R. Ultrasound Doppler renal resistive index: a useful tool for the management of the hypertensive patient. J Hypertens 2014;32:149-53.

21. Szmitko PE, Fedak PW, Weisel RD, Stewart DJ, Kutryk MJ, Verma S. Endothelial progenitor cells: new hope for a broken heart. Circulation 2003;107:3093-100.

22. Gill M, Dias S, Hattori K, Rivera ML, Hicklin D, Witte $\mathrm{L}$, et al. Vascular trauma induces rapid but transient mobilization of VEGFR2(+)AC133(+) endothelial precursor cells. Circ Res 2001;88:167-74.

23. Werner N, Junk S, Laufs U, Link A, Walenta K, Bohm M, et al. Intravenous transfusion of endothelial progenitor cells reduces neointima formation after vascular injury. Circ Res 2003;93:17-24.

24. Griese DP, Ehsan A, Melo LG, Kong D, Zhang L, Mann MJ, et al. Isolation and transplantation of autologous circulating endothelial cells into denuded vessels and prosthetic grafts: implications for cell-based vascular therapy. Circulation 2003;108:2710-5.

25. Kong D, Melo LG, Gnecchi M, Zhang L, Mostoslavsky G, Liew CC, et al. Cytokine-induced mobilization of circulating endothelial progenitor cells enhances repair of injured arteries. Circulation 2004;110:2039-46.

26. Eroglu E, Kocyigit I, Saraymen B, Tuncay A, Mavili E, Unal A, et al. The association of endothelial progenitor cell markers with arteriovenous fistula maturation in hemodialysis patients. Int Urol Nephrol 2016;48:891-9. 